Original Article

\title{
Perfil das infecções relacionadas à assistência à saúde em um centro de terapia intensiva de Minas Gerais
}

\section{Profile of healthcare-associated infections in an intensive care unit in Minas Gerais}

Perfil de las infecciones relacionadas a la asistência de la salude nun centro de terapia intensiva de Minas Gerais

Laís Santos Silva ${ }^{1}$ ORCID-0000-0002-5539-556X

Cleyde Amaral Leite ${ }^{1}$ ORCID-0000-0001-5875-337X

Mariana Roberta Lopes Simões ${ }^{1}$ ORCID-0000-0003-0543-6906

Danielle Sandra da Silva Azevedo ${ }^{1}$ ORCID-0000-0002-1203-2136

${ }^{1}$ Universidade Federal dos Vales do Jequitinhonha e Mucuri (UFVJM), Diamantina, Minas Gerais, Brazil

Authors' contributions:

Laís Santos Silva: outlined the study, collected, analyzed and discussed the data and made the necessary corrections.

Cleyde Amaral Leite: analyzed and discussed the data and made the necessary corrections. Mariana Roberta Lopes Simões: analyzed and discussed the data and made the necessary corrections.

Danielle Sandra Da Silva Azevedo: outlined the study, collected, analyzed and discussed the data and made the necessary corrections.

Submitted: 25/07/2018

Accepted: 10/09/2109

lais.ufvjm@outlook.com

Rua Vereador José Maria Moreira, n62, Datas, Minas Gerais, CEP:39130-000

\section{RESUMO}

Justificativa e Objetivos: Infecções Relacionadas à Assistência à Saúde (IRAS) constituem uma das grandes problemáticas nas unidades de saúde, principalmente no centro de terapia intensiva (CTI), devido à presença de pacientes críticos. O objetivo deste estudo foi descrever as IRAS ocorridas no CTI de um hospital geral no interior de Minas Gerais no período de 2014 a 2016. Métodos: estudo descritivo e retrospectivo com dados obtidos através de registros fornecidos pelo Serviço de Controle de Infecção Relacionada à Assistência à Saúde (SCIRAS) da instituição. Resultados: o percentual de IRAS nos anos estudados foi de 3,4\% em 2014; 2,4\% em 2015 e 1,8\% em 2016. Maior ocorrência de infecção em indivíduos com idade entre 41 a 60 anos, sendo o maior percentual no ano de 2014 (39,1\%). Em relação ao sítio de infecção, o maior registro foi de infecção do trato respiratório; 68,8\% em 2014; 54,2\% em 2015 e 51,7\% em 2016. Contudo, em todos os anos, não houve registro do tipo de agente etiológico em mais de $50 \%$ dos casos. A patologia de base mais frequente foi traumatismo cranioencefálico (TCE), que atingiu $18,6 \%$ no ano de 2015. Outro fator relevante foi o alto índice de mortalidade registrado em todos os anos, chegando a 63,8\% no ano de 2016. 
Conclusão: o levantamento dos dados acerca das IRAS no CTI evidenciou baixa ocorrência quando comparado com a literatura. Tal fato pode estar associado à subnotificação.

Palavras-chave: Infecção hospitalar. Assistência à saúde. Notificação

\begin{abstract}
Background and Objectives: Healthcare-Associated Infections (HAI) are one of the major problems in health care units, especially in the intensive care unit (ICU), due to the presence of critical patients. The objective of this study was to describe the occurrence of HAIs in the ICU of a general hospital in the inlands of Minas Gerais in the period from 2014 to 2016. Methods: descriptive and retrospective study with data obtained from the HealthcareAssociated Infection Control Service of the institution. Results: the percentage of HAIs in the years studied was $3.4 \%$ in $2014 ; 2.4 \%$ in 2015 and $1.8 \%$ in 2016 . The highest occurrence of infection was in individuals aged 41-60 years and the highest percentage was in 2014 $(39.1 \%)$. In relation to the infection site, most records were from respiratory tract infections (RTI); $68.8 \%$ in $2014 ; 54.2 \%$ in 2015 ; and $51.7 \%$ in 2016 . However, more than $50 \%$ of cases in all years did not have records of the type of etiological agent. As for the underlying pathology, the most frequent was traumatic brain injury (TBI) that affected $18.6 \%$ in 2015 . Another relevant factor was the high mortality rate recorded in all years that reached $63.8 \%$ in 2016. Conclusion: data collection on HAIs at the ICU indicated a low prevalence when compared to the literature. This may be associated with underreporting.
\end{abstract}

Keywords: Cross Infection. Healthcare. Notification

\title{
RESUMEN
}

Justificación y objetivos: Infecciones Asociadas a la Atención en Salud (IAAS) constituyen una de las grandes problemáticas en las unidades de salud, principalmente en la Unidad de Cuidados Intensivos (UCI), debido a la presencia de pacientes críticos. El objetivo de este estudio fue describir las IAAS ocurridas en la UCI de un hospital general en el interior de Minas Gerais en el período de 2014 a 2016. Métodos: estudio descriptivo y retrospectivo con datos obtenidos a través de registros proporcionados por el Servicio de Control de Infección Relacionada a la Atención en Salud de la institución. Resultados: el porcentaje de IAAS em los años estudiados fue del $3,4 \%$ en $2014 ; 2,4 \%$ en 2015 y 1,8\% en 2016. La mayor incidencia de infección fue en individuos de 41 a 60 años y el porcentaje más alto fue en el año $2014(39,1 \%)$. Con respecto al sitio de la infección, el mayor registro fue de infección del tracto respiratorio; $68,8 \%$ en $2014 ; 54,2 \%$ en 2015 y 51,7\% en 2016. Sin embargo, más del $50 \%$ de los casos en todos los años no tenían registros del tipo de agente etiológico. En cuanto a la patología subyacente, la más frecuente fue la lesión cerebral traumática, que afectó al $18,6 \%$ en el año 2015. Otro factor relevante fue la alta tasa de mortalidad registrada en todos los años, que alcanzó el 63,8\% en el año de 2016. Conclusiones: la recopilación de datos sobre las IAAS en la UCI indicó una baja prevalencia en comparación con la literatura. Esto puede estar asociado con el subregistro.

Palabras clave: Infección hospitalaria. Prestación de Atención de Salud. Registro.

\section{INTRODUCTION}


The Centers for Disease Control and Prevention (CDC) define Healthcare-Associated Infections (HAIs) as any infection acquired by an individual during treatment at the health facility, whether in the hospital or outpatient care, long-term or short-term care, which may manifest in a systemic or local manner. ${ }^{1}$ In Brazil, HAIs are infections acquired after the patient's admission and manifested during hospitalization or after discharge, when related to hospitalization or hospital procedures. ${ }^{2}$

On the one hand, scientific and technological advances enabled the creation of new therapeutic procedures that increased the survival of sick patients, but on the other hand, patients were exposed to a higher risk of developing HAIs. ${ }^{3}$ Healthcare-Associated Infections represent an imbalance between the body's natural microbiota and the defense mechanisms commonly observed in severely ill patients. ${ }^{4}$ The pathogens involved in HAIs are transmitted to the individual either endogenously, that is, through the patient's own microbiota, or through the exogenous route by the hands, salivary secretion, body fluids, air and contaminated materials. ${ }^{5}$

Healthcare-Associated Infections are even more significant in the intensive care unit (ICU) due to the presence of critically ill patients. Although this sector represents less than $2 \%$ of hospital beds available, it contributes to more than $25 \%$ of hospital infections, with significant impact on morbidity and mortality rates. ${ }^{6}$ HAIs are associated with clinical severity of patients, immune system disorders, use of numerous invasive procedures, use of immunosuppressants, prolonged hospitalization, colonization by resistant microorganisms, prescription of antimicrobials, therapeutic dehydration and the ICU environment itself that favors the natural selection of microorganisms. ${ }^{7,8}$

Another factor directly associated with HAIs is poor hand hygiene, which is considered the most important, inexpensive, and effective measure for the prevention and control of HAIs. Although this procedure is supported by sound scientific evidence, its adherence is still described as insufficient in the literature. ${ }^{9}$ The hands of health professionals are known as the most common route of transmission of infectious agents causing HAIs, although the transmission is complex and multifactorial. ${ }^{10}$

The most frequent sites of HAI are urinary tract infections (UTI), respiratory tract infections (RTI), surgical site infections (SSI), and bloodstream infections (BSI). ${ }^{11}$

HAIs have negative repercussions and serious consequences, such as increased morbidity and mortality and general expenses. In addition, they lead to a longer length of stay 
of patients and withdrawal from the family environment, negatively impacting the quality of life of all involved. ${ }^{12,13}$

In Brazil, the average rate of nosocomial infection is $15.5 \%$, which corresponds to 1.18 episodes of infection per patient hospitalized with HAIs, i.e., the same patient acquired more than one infection. ${ }^{14}$ HAIs are considered one of the leading causes of in-hospital mortality. ${ }^{3}$

The occurrence of HAI is related to the vulnerability of patients and to the adherence of health professionals for the prevention and control of infection in the hospital environment. Therefore, it is mandatory that health services/hospitals have a Healthcare-Associated Infection Control Commission to reduce and control the incidence and worsening of HAIs.

The aim of this study was to analyze the profile of HAIs in an ICU of a medium-sized hospital in the inlands of the state of Minas Gerais. The elucidation of some epidemiological aspects of this theme can help the implementation of preventive actions for the better quality of care provision.

\section{METHODS}

This is a descriptive and retrospective study conducted at the Santa Casa de Caridade in the municipality of Diamantina, Minas Gerais. In 2014, this medium-sized hospital had 102 beds, of which ten belonged to the ICU. In 2015, after a renovation of the hospital, the ICU had 20 beds and the institution had 112 beds. The hospital has multidisciplinary teams and 454 employees, in total.

The institution has a Healthcare-Associated Infection Control Commission and a Healthcare-Associated Infection Control Service with a physician and a nurse specialized in the area and a nursing technician. These professionals perform epidemiological surveillance of HAIs through the Diagnostic Criteria for HAI established by the National Health Surveillance Agency (Portuguese acronym: ANVISA).

This study included all patients admitted to the ICU with HAI notification registered by the Healthcare-Associated Infection Control Service of the referred hospital during the study period. The collection was made through a retrospective survey of HAIs registered in the Healthcare-Associated Infection Control Service with use of a form prepared by the authors that included sociodemographic characteristics and infection characteristics available in the records.

The exclusion criteria were all patients admitted to the ICU who did not have HAIs during the hospitalization period or were admitted with non-hospital related infections. 
The variable of interest was the healthcare-associated infection. The other variables included sociodemographic characteristics of sex and age, as well as infection characteristics, namely: sites of infection, type of etiological agent, underlying pathology and clinical outcome after HAI occurrence.

The percentage of the outcome and the other variables were analyzed using the statistical software SPSS, version 20.0. The study complied with the ethical precepts for research involving human beings of Resolution 466/12 CNS and was approved by the Research Ethics Committee of the Universidade Federal dos Vales do Jequitinhonha e Mucuri (CAAE/UFVJM number 70164017.9.0000.5108).

\section{RESULTS}

In the study, were analyzed 181 HAI records notified by the Healthcare-Associated Infection Control Service from 2014 to 2016, with 64 records (35.3\%) in 2014, 59 records (32.6\%) in 2015 and 58 records (32\%) in 2016. Considering the number of patients admitted to the ICU during the study period, i.e., 1844 in 2014, 2411 in 2015 and 3114 in 2016, the percentage of HAIs was $3.4 \%$ in 2014, 2.4\% in 2015 and $1.8 \%$ in 2016.

Regarding sociodemographic characteristics, there was a higher frequency in male subjects compared to females. The most frequent age group among individuals with HAIs was 21 to 60 years, especially in patients aged 41 to 60 years (Table 1).

Table 1. Distribution of the number of HAIs notifications from 2014 to 2016 according to sex and age. Diamantina/MG, 2018.

\begin{tabular}{lcccc}
\hline Variables & $\begin{array}{c}\mathbf{2 0 1 4} \\
\mathbf{N}(\boldsymbol{\%})\end{array}$ & $\begin{array}{c}\mathbf{2 0 1 5} \\
\mathbf{N}(\boldsymbol{\%})\end{array}$ & $\begin{array}{c}\mathbf{2 0 1 6} \\
\mathbf{N}(\boldsymbol{\%})\end{array}$ & $\begin{array}{c}\text { Total } \\
\mathbf{N}(\boldsymbol{\%})\end{array}$ \\
\hline Age & & & & \\
0 to 20 years & $4(6.3)$ & $3(5.1)$ & $7(12.1)$ & $14(7.7)$ \\
21 to 40 years & $20(31.3)$ & $20(33.9)$ & $10(17.2)$ & $50(27.6)$ \\
41 to 60 years & $25(39.1)$ & $16(27.1)$ & $21(36.2)$ & $62(34.2)$ \\
61 to 80 years & $12(18.8)$ & $16(27.1)$ & $18(31)$ & $46(25.4)$ \\
81 to 100 & $3(4.7)$ & $4(6.8)$ & $2(3.4)$ & $9(4.9)$ \\
years & & & & \\
Sex & & & & \\
Female & $18(28.1)$ & $31(52.5)$ & $20(34.5)$ & $69(38.1)$ \\
Male & $46(71.9)$ & $28(47.5)$ & $38(65.5)$ & $112(61.8)$ \\
& & & & \\
\hline
\end{tabular}


Regarding the site of infection, in all years, the most frequently recorded topography was respiratory tract infection (RTI), accounting for $68.8 \%$ of notifications in $2014 ; 52.4 \%$ in 2015; and $51.7 \%$ in 2016. (Table 2).

Table 2. Distribution of the number of IRAS notifications between years 2014 and 2016 according to the infection characteristics. Diamantina/MG, 2018.

\begin{tabular}{|c|c|c|c|c|}
\hline Variables & $\begin{array}{l}2014 \\
\text { N }(\%)\end{array}$ & $\begin{array}{l}2015 \\
\text { N (\%) }\end{array}$ & $\begin{array}{l}2016 \\
\text { N }(\%)\end{array}$ & $\begin{array}{l}\text { Total } \\
\text { N }(\%)\end{array}$ \\
\hline \multicolumn{5}{|l|}{ Infection site } \\
\hline $\mathrm{RTI}^{*}$ & $44(68.8)$ & $32(54.2)$ & $30(51.7)$ & $106(58.5)$ \\
\hline UTI* & $1(1.6)$ & $3(5.1)$ & $5(8.6)$ & $9(4.9)$ \\
\hline BSI* & $9(14.1)$ & $14(23.7)$ & $3(5.2)$ & $26(14.3)$ \\
\hline SSI* & $1(1.6)$ & $1(1.7)$ & $1(1.7)$ & $3(1.6)$ \\
\hline Meningitis & $3(4.7)$ & $3(5.1)$ & $10(17.2)$ & $16(8.8)$ \\
\hline Others & $6(9.4)$ & $6(10.2)$ & $9(15.5)$ & $21(11.6)$ \\
\hline \multicolumn{5}{|l|}{ Microorganisms } \\
\hline Staphylococcus aureus & $8(12.5)$ & $11(18.6)$ & $1(1.7)$ & $20(11)$ \\
\hline Proteusmirabilis & $3(4.7)$ & $4(6.8)$ & $5(8.6)$ & $12(6.6)$ \\
\hline Proteusvulgaris & $1(1.6)$ & $5(8.5)$ & $3(5.2)$ & $9(4.9)$ \\
\hline $\begin{array}{l}\text { Pseudomonas } \\
\text { aeruginosa }\end{array}$ & $5(7.8)$ & $2(3.4)$ & $2(3.4)$ & $9(4.9)$ \\
\hline Others & $(4.6)$ & $5(8.5)$ & $3(5.2)$ & $11(6)$ \\
\hline Not informed & $44(68.8)$ & $32(54.2)$ & $44(75.9)$ & $120(66.3)$ \\
\hline \multicolumn{5}{|l|}{ Underlying pathology } \\
\hline $\mathrm{CVA}^{*}$ & $2(3.1)$ & $14(23.7)$ & $11(19)$ & 27 (14.9) \\
\hline TBI* & $11(17.2)$ & $11(18.6)$ & $11(19)$ & $33(18.2)$ \\
\hline Spinal Cord Injury & $2(3.1)$ & $1(1.7)$ & $1(1.7)$ & $4(2.2)$ \\
\hline Others & $27(42.2)$ & $19(32.3)$ & $22(37.9)$ & $68(37.5)$ \\
\hline Not informed & $22(34.4)$ & $14(23.7)$ & $13(22.4)$ & $49(27)$ \\
\hline \multicolumn{5}{|l|}{ Clinical outcome } \\
\hline Discharge & $37(57.8)$ & $44(74.6)$ & $21(36.2)$ & $102(56.3)$ \\
\hline Death & $27(42.2)$ & $15(25.4)$ & $37(63.8)$ & $79(43.6)$ \\
\hline
\end{tabular}

* RTI: respiratory tract infection; UTI: urinary tract infection; BSI: bloodstream infection; SSI: surgical site infection; CVA: cerebrovascular accident; TBI: traumatic brain injury.

Regarding microorganisms, the main pathogen reported was Staphylococcus Aureus, with a percentage of $12.5 \%$ in $2014,18.6 \%$ in 2015 and $1.7 \%$ in 2016 . However, most 
registration forms did not contain records of the etiological agent, representing a percentage of $68.8 \%$ in $2014,54.2 \%$ in 2015 and $75.9 \%$ in 2016.

In all years, the most common underlying pathology was traumatic brain injury (TBI), which affected $17.2 \%$ of the sample in 2014, 18.6\% in 2015 and 19\% in 2016; followed by cerebrovascular accident (CVA) affecting 3.1\% in 2014, 23.7\% in 2015 and 19\% in 2016. The information about underlying pathology was also lacking in the notification forms, with percentages of $34.4 \%$. in $2014,23.7 \%$ in 2015 and $22.4 \%$ in 2016.

Clinical discharge was the most registered clinical outcome of notified patients, and reached $57.8 \%$ in $2014,74.6 \%$ in 2015 and $36.2 \%$ in 2016. The clinical outcome of death affected $42.2 \%$ of the sample in $2014,25.4 \%$ in 2015 and $63.8 \%$ in 2016.

\section{DISCUSSION}

Healthcare-Associated Infections are a serious public health problem, as they increase morbidity and mortality rates, hospitalization costs, the length of stay of patients, and account for the high death rates characteristic of the ICU because this is a critical sector. ${ }^{15}$

Of the total number of patients admitted to the ICU, the percentage of HAIs was $3.4 \%$ in $2014 ; 2.4 \%$ in 2015 and $1.8 \%$ in 2016 . Healthcare-Associated Infection rates are higher in large and teaching hospitals and vary according to the type of surveillance used and the degree of complexity of the hospital. Infection rates in the ICU range from 18 to $54 \%$ and are five to ten times higher than in other inpatient units. ${ }^{15}$ In the institution of the present study, was found a low percentage, possibly because the ICU attends all levels of complexity and the number of beds was duplicated after the renovation performed during the study period. In addition, until 2016, the Healthcare-Associated Infection Control Commission was not active in the institution, since there was no nurse exclusively for the sector and no electronic medical records were used, thus hindering the investigations of HAIs, which may have led to underreporting.

On average, the highest frequency of HAI reports occurred in male subjects (61.8\%), corroborating other studies. In a study conducted in a general hospital in Bahia, $85.8 \%$ of patients were male ${ }^{4}$ and in Belo Horizonte, $54.7 \%$ of adult ICU patients were also men. ${ }^{16}$ This occurrence seems to be related to the larger number of men admitted to this hospital sector.

Regarding age, there was a higher frequency of HAIs in patients aged 41 to 60 years. A study conducted in an ICU of a teaching hospital in Fortaleza also found a mean age of 58.3 
years. ${ }^{3}$ Such age marks the beginning of the elderly phase and the physiological effects of aging that may lead to a higher risk of health problems, especially in ICU patients. ${ }^{17}$

The most prevalent infection site was the respiratory tract with an average of $58.5 \%$. The same result was found in an ICU located in São Paulo (59\%). ${ }^{18}$ In another study conducted in a public hospital in the inlands of Paraná, RTIs were also more prevalent $(36.4 \%) .{ }^{19}$ These results suggest that the use of a mechanical ventilator associated with prolonged use of this device and patients' organic weaknesses may lead to the higher occurrence of HAIs. ${ }^{14}$

Considering the reported pathogens, Staphylococcus aureus was the most frequent, with an average of $32.7 \%$ over the years, corroborating a study conducted in a public hospital in the inlands of Rondônia that recorded a rate of $23.8 \% .^{20}$ Studies point out that Staphylococcus aureus is considered one of the major human pathogens, usually present in the nasal cavities, skin and intestine, and most often transmitted by the hands of healthcare professionals when hand hygiene is insufficient. ${ }^{21}$

In the present study, TBI was the most prevalent underlying pathology, which is an important risk factor for the development of HAIs because it may depress the immune system and facilitate the pathogen invasion. ${ }^{22}$ A study conducted at a university hospital on the characteristics of infections and the health impact of trauma patients showed that $15.6 \%$ of patients acquired at least one infection during hospitalization. Economically active individuals are more susceptible to accidents arising from external causes, especially land transport accidents. $^{23}$

Although hospital discharge was the most frequent outcome, the registration of deaths, especially in 2016, was relevant (63.8\%). In a study on mortality and risks associated with HAIs conducted in a teaching hospital in Paraná, was recorded a mortality rate of $38.4 \%{ }^{24}$. Studies show that mortality in ICUs is generally high, with rates ranging from 9 to $38 \%$. And when it comes to death in patients who develop HAIs, it can reach $70 \%{ }^{16}$

The results presented in this investigation should be interpreted with caution. In addition to the limitation of the study design, data comparison may have been impaired due to different data collection techniques. Still, the number of variables reinforces the relevance of the findings.

The survey of data on HAIs at the ICU showed low occurrence compared to the literature. However, specificities in the sector during the study period may explain the strong underreporting. The difficulty of finding information in the notification forms reinforces the need for the complete registration and the importance of active case search. 
The eradication of HAIs is an arduous task given the underlying pathology presented by the patient and the HAI etiology. However, prevention and control have proven effective in reducing infections. Actions of permanent and continuing education established by the Healthcare-Associated Infection Control Commission are extremely important tools for the awareness and learning of health professionals. We suggest the continuous dissemination of results obtained by the Healthcare-Associated Infection Control Service through emphasis on the measures that generated positive results with the performance of educational activities.

\section{REFERENCES}

1. CDC. Healthcare-Associated Infection (HAI) Prevention Plan. Disponível em: <https://www.cdc.gov/hai/pdfs/stateplans/wy.pdf>. Acesso em: 06 de agosto de 2018.

2. Ministério da Saúde (BR). Portaria no 2616 de 12 de maio de 1998. Expede diretrizes e Normas para a Prevenção e Controle das Infecções Hospitalares. Diário Oficial da União, Brasília (DF), 1998 maio 13. Sessão 1

3. Pereira FGF, Chagas ANS, Freitas MMC, et al. Caracterização das infecções relacionadas à assistência à saúde em uma Unidade de Terapia Intensiva. VigilSanit Debate 2016; 4(1): 70-77. http://doi.org/10.3395/2317-269x.00614.

4. Oliveira TFL, Filho ISG, Passos JS, et al. Factors associated with nosocomial pneumonia in hospitalized individuals. Journal Brazilian Medical Association 2011; 57(6): 630-636. http://dx.doi.org/10.1590/S0104-42302011000600008.

5. Garcia LM, César ICO, Braga CA, et al.Perfil epidemiológico das infecções hospitalares por bactérias multidrogarresistentes em um hospital do norte de Minas Gerais. RevEpidemiolControlInfect2013; 3(2): 45-49. http://dx.doi.org/10.17058/reci.v3i2.3235.

6. Bork LCA, Gaspar MDR, Reche PM. Adesão às medidas preventivas de pneumoniaassociada à ventilação mecânica. RevEpidemiolControlInfect2015; 5(1): 12-16. http://dx.doi.org/10.17058/reci.v5i1.4885.

7. Oliveira AC, Kovner CT, Silva RS. Nosocomial infection in an intensive care unit in a Brazilian university hospital. Latin American Journal of Nursing, 2010; 18(2): 233239. http://dx.doi.org/10.1590/S0104-11692010000200014.

8. Albuquerque AM, Souza APM, Torquato IMB, Trigueiro JVS, Ferreira JA, Ramanho MAN. Infecção cruzada no Centro de Terapia Intensiva à luz da literatura. Rev. Ciênc. Saúde Nova Esperança [internet] 2013 [citado 2018 abr 12]; 11(1): 78-87. Disponível 
em:

http://www.facene.com.br/wpcontent/uploads/2010/11/INFEC\%E2\%94\%9C\%2587\%E2\%94\%9C\%2583OCRUZADA-NO-CENTRO-.pdf

9. Anacleto ASCB, Peterlini MAS, Pedreira MLG. Hand hygiene as a caring practice: a reflection on professional responsibility. BrazilianJournalofNursing, 2017; 70(2): 442445. http://dx.doi.org/10.1590/0034-7167-2016-0189.

10. Graveto JM, Santos C, Costa OS, et al. Hand hygiene management among nurses: collective health challenges. Brazilian Journal of Nursing, [internet] 2018 [citado 2018 ago 6]; 71(Supl 1) 562- 567. Disponívelem: http://www.scielo.br/pdf/reben/v71s1/0034-7167-reben-71-s1-0562.pdf

11. Tavares CA, Veras MCB, Silva ACR, et al. Avaliação da prescrição de antimicrobianos para infecção relacionada à assistência à saúde em um Hospital Escola de Recife - PE. RevEpidemiolControlInfect 2015; 5(3): 123-130. http://dx.doi.org/10.17058/reci.v5i3.5496.

12. Nangino GO, Oliveira CD, Correia PC, et al. Financial impact of nosocomial infections in the intensive care units of a charitable hospital in Minas Gerais, Brazil. Brazilian Journal of Intensive Care 2012; 24(4): 357-361. http://dx.doi.org/10.1590/S0103-507X2012000400011.

13. Magdelijns FJH, Stassen PM, Stehouwer CDA, et al. Direct health care costs of hospital admissions due to adverse events in the Netherlands. European Journal of Public Health, 2014; 24(6): 1028-1033. https://doi.org/10.1093/eurpub/cku037

14. Cândido RBR, Souza WA, Podestá MHMC, et al. Avaliação das infecções hospitalares em pacientes críticos em um Centro de Terapia Intensiva. Rev. Univers. $\begin{array}{lllll}\text { Vale } & \text { do } & \text { Rio } & \text { Verde. } & \text { 2012; }\end{array}$ http://dx.doi.org/10.5892/ruvrv.2012.102.148163

15. Santos AV, Silva MRP, Carvalho MM, et al. Profile of hospital infections in the intensive care units of an emergency hospital. J Nurs UFPE 2016; 10(Supl.1): 194 201. DOI: 10.5205/reuol.7901-80479-1-SP.1001sup201601

16. Oliveira AC, Paula AO,Iquiapaza RA, et al. Infecções relacionadas à assistência em saúde e gravidade clínica em uma unidade de terapia intensiva. Rev. Gaúcha Enferm 2012; 33(3): 89-96. http://dx.doi.org/10.1590/S1983-14472012000300012

17. Cabral FW, Silva MZO. Prevenção e controle de infecções no ambiente hospitalar. Sanare Sobral, [internet] 2013 [citado 2018 abr 16]; 12(1): 59-70. Disponível em: https://sanare.emnuvens.com.br/sanare/article/viewFile/330/264 
18. Santos RB, Duran ECM, Carmona EV, et al. Diagnósticos de enfermagem em pacientes com infecção hospitalar. Revenferm UFPE 2015; 9(Supl. 8): 9359-9365. DOI: 10.5205/reuol.6812-75590-1-ED.0908sup201504.

19. Santos RP, Mariano LR, Takahashi LS, et al. Prevalência de infecção hospitalar em unidade de terapia intensiva - um estudo retrospectivo. RevEnferm UFSM 2014; 4(2): 410-418. http://dx.doi.org/10.5902/2179769211233.

20. Costa LF, Souza LP, Lima MG. Agentes etiológicos mais frequentes em pontas de cateteres venosos centrais em unidade de terapia intensiva - UTI. Braz. J. Surg. Clin. Res. [internet] 2014 [citado 2018 mai 7]; 6(2): 18-23.Disponível em: https://www.mastereditora.com.br/periodico/20140331_212351.pdf

21. Teixeira AA, Risola BM, Neto HPD, et al. Avaliação da contaminação por Staphylococcus aureus resistente a droga beta-lactâmica de estetoscópios dos profissionais de um Hospital Escola em uma cidade do interior do Rio de Janeiro. Rev. Saber Digital [internet] 2017 [citado 2018 mai 11]; 9(2): 117-128. Disponível em: http://revistas.faa.edu.br/index.php/SaberDigital/article/view/214/176

22. Silva JVF, Rodrigues APRA. A infecção nosocomial em unidade de terapia intensiva neonatal. Ciências Biológicas e da Saúde [internet] 2015 [citado 2018 mai 17]; 3(1): 129-138.

Disponível

em: https://periodicos.set.edu.br/index.php/fitsbiosaude/article/viewFile/2633/1496

23. Watanabe EM, Almeida VF, Ottunes AF, et al. Impacto das infecções relacionadas àassistência à saúde em pacientes acometidos por trauma. CiêncBiol Saúde 2015; 36(1): 89-98. http://dx.doi.org/10.5433/1679-0367.2015v36n1Suplp89

24. Souza ES, Belei RA, Carrilho CMDM, et al. Mortality and risks related to healthcareassociated infection. Text Context Nursing 2015; 24(1): 220-228. http://dx.doi.org/10.1590/0104-07072015002940013. 